\title{
Towards sex identification of Asian Palmyra palm (Borassus flabellifer L.) by DNA fingerprinting, suppression subtractive hybridization and de novo transcriptome sequencing
}

Kwanjai Pipatchartlearnwong ${ }^{1}$, Piyada Juntawong ${ }^{1,2,3}$, Passorn Wonnapinij ${ }^{1,2,3}$, Somsak Apisitwanich ${ }^{1,2}$, Supachai Vuttipongchaikij ${ }^{\text {Corresp. 1, 2, } 3}$

${ }^{1}$ Department of Genetics, Faculty of Science, Kasetsart University, Bangkok, Thailand

2 Center of Advanced studies for Tropical Natural Resources, Kasetsart University, Bangkok, Thailand

3 Omics Center for Agriculture, Bioresources, Food and Health, Kasetsart University (OmiKU), Bangkok, Thailand

Corresponding Author: Supachai Vuttipongchaikij

Email address: fsciscv@ku.ac.th

Background. Asian Palmyra palm, the source of palm-sugar, is dioecious with a long juvenile period requiring at least 12 years to reach its maturity. To date, there is no reliable molecular marker for identifying sexes before the first bloom, limiting crop designs and utilization. We aimed to identify sexlinked markers for this palm using PCR-based DNA fingerprinting, suppression subtractive hybridization (SSH) and transcriptome sequencing.

Methods. DNA fingerprints were generated between males and females based on RAPD, AFLP, SCoT, modified SCOT, ILP, and SSR techniques. Large-scale cloning and screening of SSH libraries and de novo transcriptome sequencing of male and female cDNA from inflorescences were performed to identify sexspecific genes for developing sex-linked markers.

Results. Through extensive screening and re-testing of the DNA fingerprints (up to 1,204 primer pairs) and transcripts from SSH (>10,000 clones) and transcriptome data, however, no sex-linked marker was identified. Although de novo transcriptome sequencing of male and female inflorescences provided $\sim 32$ million reads and 187,083 assembled transcripts, PCR analysis of selected sex-highly represented transcripts did not yield any sex-linked marker. This result may suggest the complexity and small sexdetermining region of the Asian Palmyra palm. To this end, we provide the first global transcripts of male and female inflorescences of Asian Palmyra palm. Interestingly, sequence annotation revealed a large proportion of transcripts related to sucrose metabolism, which corresponds to the sucrose-rich sap produced in the inflorescences, and these transcripts will be useful for further understanding of sucrose production in sugar crop plants. Provided lists of sex-specific and differential-expressed transcripts would be beneficial to the further study of sexual development and sex-linked markers in palms and related species. 
1 Towards sex identification of Asian Palmyra palm (Borassus flabellifer L.) by

2 DNA fingerprinting, suppression subtractive hybridization and de novo

3 transcriptome sequencing

5 Kwanjai Pipatchartlearnwong ${ }^{1}$, Piyada Juntawong ${ }^{1,2,3}$, Passorn Wonnapinij ${ }^{1,2,3}$, Somsak

6 Apisitwanich ${ }^{1,2}$, Supachai Vuttipongchaikij ${ }^{1,2,3}$

$8{ }^{1}$ Department of Genetics, Faculty of Science, Kasetsart University, Bangkok 10900, Thailand

$9{ }^{2}$ Center of Advanced studies for Tropical Natural Resources, Kasetsart University, Bangkok

10 10900, Thailand

$11{ }^{3}$ Omics Center for Agriculture, Bioresources, Food and Health, Kasetsart University (OmiKU),

1250 Ngarm Wong Wan road, Chatuchak, Bangkok 10900, Thailand

15 Corresponding Author:

16 Supachai Vuttipongchaikij

17 Department of Genetics, Faculty of Science, Kasetsart University, 50 Ngam Wong Wan Road,

18 Chatuchak, Bangkok 10900, Thailand

19 Email address: fsciscv@ku.ac.th 


\section{Abstract}

21 Background. Asian Palmyra palm, the source of palm-sugar, is dioecious with a long juvenile

22 period requiring at least 12 years to reach its maturity. To date, there is no reliable molecular

23 marker for identifying sexes before the first bloom, limiting crop designs and utilization. We

24 aimed to identify sex-linked markers for this palm using PCR-based DNA fingerprinting,

25 suppression subtractive hybridization ( $\mathrm{SSH})$ and transcriptome sequencing.

26 Methods. DNA fingerprints were generated between males and females based on RAPD, AFLP,

27 SCoT, modified SCoT, ILP, and SSR techniques. Large-scale cloning and screening of SSH

28 libraries and de novo transcriptome sequencing of male and female cDNA from inflorescences

29 were performed to identify sex-specific genes for developing sex-linked markers.

30 Results. Through extensive screening and re-testing of the DNA fingerprints (up to 1,204

31 primer pairs) and transcripts from $\mathrm{SSH}$ (>10,000 clones) and transcriptome data, however, no

32 sex-linked marker was identified. Although de novo transcriptome sequencing of male and

33 female inflorescences provided $\sim 32$ million reads and 187,083 assembled transcripts, PCR

analysis of selected sex-highly represented transcripts did not yield any sex-linked marker. This

result may suggest the complexity and small sex-determining region of the Asian Palmyra palm.

To this end, we provide the first global transcripts of male and female inflorescences of Asian

37 Palmyra palm. Interestingly, sequence annotation revealed a large proportion of transcripts

38 related to sucrose metabolism, which corresponds to the sucrose-rich sap produced in the

39 inflorescences, and these transcripts will be useful for further understanding of sucrose

40 production in sugar crop plants. Provided lists of sex-specific and differential-expressed

41 transcripts would be beneficial to the further study of sexual development and sex-linked

42 markers in palms and related species. 
43

44

45

46

47

48

49

50

51

52

53

54

55

56

57

58

59

60

61

62

63

64

65

66

\section{Introduction}

44

5

perennial tree, requiring 12-15 years to reach its maturity and produce the first inflorescence (Kovoor, 1983). Once flowered, it vigorously and continuously produces flowers and fruits through its lifespan. This palm is found widespread in South and Southeast Asia and provides essential food and economic values throughout its parts including inflorescence sap for producing palm sugar and alcoholic beverages, fruits for consumption and the tree trunk for construction (Morton, 1988; Lim, 2012). Both sexes are morphologically identical except for the male and female inflorescences, and there are no reliable means of sex identification before the first bloom. Because of the long juvenile period and a preference for female plants for fruit production, growers hesitate to expand the plantation, and this limits the utilization of this palm. Being able to identify the sexes of Asian Palmyra palm at seedling stages will provide better designs for the crop production through optimal male and female ratios, breeding programs, conservation and utilization (Davis \& Johnson, 1987; Barfod et al., 2015; Sirajuddin et al., 2016). Molecular markers for sex identification in Asian Palmyra palm is needed.

Asian Palmyra palm belongs to family Arecaceae, which includes many palm species that are among the world commercially important crops, including oil palm (Elaeis oleifera), coconut (Cocos nucifera) and date palm (Phoenix dactylifera) (Beck \& Balick, 1990; Dransfield et al., 2005). Historically, it was placed among these valued crops as for producing palm sugar, alcohol products and its nutritious fruits dating back at least 2,500 years (Fox, 1977; Ferguson, 1888), before sugarcane gradually replaced its status. Historical and genetic studies suggest that Asian

64 Palmyra palm was originated from tropical Africa, brought along the spice route to the east and 65 settled in the Indian subcontinent, where it is widely propagated throughout India and Sri Lanka, before introduced to Southeast Asia more than 1,500 years ago (Pipatchartlearnwong et al., 
67 2017a). Given its extended benefits since the historical time and because of its vigorous growth

68 and continuous supply of inflorescence sap and fruits with the ability to withstand severe

69 climate, arid conditions, pests and diseases, Asian Palmyra palm should be recognized as a

70 potential recalcitrant food crop to the climate change for the tropical and subtropical regions.

71 Molecular data of Asian Palmyra palm are currently limited. The genome sequence is not

72 available, and only its chloroplast genome was recently reported (Sakulsathaporn et al., 2017). A

73 few sex-linked markers have been developed based on DNA fingerprinting, but only one RAPD-

74 based marker was shown to be able to identify the sexes among the populations in India (George

75 et al., 2007). However, our preliminary experiment showed that this marker was unable to

76 identify the sexes in the population in Thailand. Previously, we showed that Asian Palmyra palm

77 populations in Thailand are descended from a small number of seedlings brought in at least 1,500

78 years ago and represent a very narrow genetic diversity (Pipatchartlearnwong et al., 2017a;

79 2017b).

80 In this work, we aimed to develop sex-linked markers of Asian Palmyra palm through

81 three approaches: DNA fingerprinting, direct cloning of subtraction subtractive hybridization

82 ( $\mathrm{SSH}$ ) of cDNA from male and female inflorescences and de novo transcriptome sequencing of

83 male and female inflorescences. Extensive sets of PCR primers belonging to different DNA

84 fingerprinting techniques including RAPD, AFLP, SCoT, ILP, TEs, EST-SSR and gSSR and

85 those that specific to transcripts identified from SSH and transcriptome analysis were

86 exhaustively tested to identify sex-linked markers. Although none of the sex-linked markers was

87 obtained from this study, we have narrowed the path towards the sex identification of Asian

88 Palmyra palm. Because identifying sex-linked markers for this species appeared to be extremely

89 difficult as opposed to works in other dioecious plants (Heikrujam et al., 2015), we discussed the 
90 nature of this work in conjunction with others successfully identified markers with future

91 directions. Furthermore, this work provided the first de novo transcriptome sequencing of Asian

92 Palmyra palm. Lists of candidate transcripts that are specific to sexes and developmental stages

93 of male and female inflorescences are presented, and these will be useful for further study on sex

94 determination, sexual development and floral development of Asian Palmyra palm.

95

96

97

98

99 was pulverized into fine powder in liquid $\mathrm{N}_{2}$ by using a mortar and pestle and mixed with CTAB

111 extraction buffer [2\% (w/v) CTAB, $100 \mathrm{mM}$ Tris-HCl pH.8, $20 \mathrm{mM}$ EDTA and $1.4 \mathrm{M} \mathrm{NaCl}, 2 \%$

112 (w/v) polyvinylpyrrolidone-90 and 2\% (v/v) $\beta$-mercaptoethanol]. RNA was then precipitated 
113 using $1 / 3$ volume of $10 \mathrm{M} \mathrm{LiCl}$ at $-20^{\circ} \mathrm{C}$ for overnight and then centrifuged at $11,750 \times \mathrm{g}$ at $4{ }^{\circ} \mathrm{C}$

114 for 30 min. Total RNA was treated with DNase I (New England BioLabs ${ }^{\circledR}$ Inc., USA) at $37^{\circ} \mathrm{C}$

115 for 30 min followed by phenol: chloroform extraction and ethanol precipitation. RNA quality

116 and quantity were analyzed by agarose gel electrophoresis and NanoDrop (Thermo Scientific, 117 USA).

118

119 DNA fingerprinting

120 The RAPD-based OPA-06 marker was conducted according to George et al. (2007)

121 using total DNA from 20 male and 20 female samples. AFLP analysis was performed using 26

122 male and 46 female samples by, firstly, restriction digestion of $250 \mathrm{ng}$ total DNA using EcoRI

123 and MseI (Thermo Fisher Scientific, USA) and adaptor ligation. And, secondly, pre-selective

124 amplification was performed in a $25 \mu 1$ reaction volume containing $2 \mu 1$ of the digested DNA, 5

$125 \mathrm{mM}$ dNTPs, $40 \mathrm{mM} \mathrm{MgCl2}, 5 \rho \mathrm{M}$ of each MseI adaptor $+\mathrm{C}$ and EcoRI adaptor $+\mathrm{A}$ primers and 1

126 unit of Taq DNA polymerase (Vivantis, Malaysia) using the conditions as follows: 20 cycles of

$12794^{\circ} \mathrm{C}$ for $30 \mathrm{~s}, 56^{\circ} \mathrm{C}$ for $1 \mathrm{~min}$ and $72^{\circ} \mathrm{C}$ for $1 \mathrm{~min}$, with a final extension step at $72^{\circ} \mathrm{C}$ of $5 \mathrm{~min}$.

128 The reaction was diluted 20 -fold using $\mathrm{dH}_{2} \mathrm{O}$ before being used in a selective amplification

129 reaction: $25 \mu \mathrm{l}$ total volume containing $5 \mu \mathrm{l}$ of the diluted DNA, $4 \mathrm{mM}$ dNTPs, $40 \mathrm{mM} \mathrm{MgCl} 2,5$

$130 \rho \mathrm{M} \mathrm{MseI}+3$ and $5 \rho \mathrm{M}$ of EcoRI+3 primers (Table S1) and 1 unit of Taq DNA polymerase using

131 a touch-down condition $\left(12\right.$ cycles of $94^{\circ} \mathrm{C}$ for $30 \mathrm{~s}, 65^{\circ} \mathrm{C}\left(-0.7^{\circ} \mathrm{C} / \mathrm{cycle}\right)$ for $30 \mathrm{~s}$ and $72^{\circ} \mathrm{C}$ for 1

$132 \mathrm{~min}$, followed by 23 cycles using the annealing temperature at $56^{\circ} \mathrm{C}$ ). SCoT was performed

133 using cDNA from four male and four female samples. SCoT primers were based on Collard and

134 Mackill (2009) (Table S2). The PCR reaction was performed in a $20 \mu$ l volume, which included

$13550 \mathrm{ng}$ of DNA, $4.8 \mathrm{mM}$ dNTPs, $30 \mathrm{mM} \mathrm{MgCl2,} 20 \rho \mathrm{M}$ SCoT primer and 1 unit of Taq 
136 polymerase (Vivantis, Malaysia) using 35 cycles of $94^{\circ} \mathrm{C}$ for $1 \mathrm{~min}, 50^{\circ} \mathrm{C}$ for 1 min and $72^{\circ} \mathrm{C}$ for

$1372 \mathrm{~min}$, with a final extension for $5 \mathrm{~min}$. The modified SCoT method was performed by mixing

138 SCoT primers with primers from polyA, EST-SSRs of oil palm and transposon element (TE)

139 markers (Table S3 and S4) (Bureau and Wessler, 1994; Takata, Kishima \& Sano, 2005). ILP

140 marker based on Ukoskit and U-thoomporn (2016) (Table S5) was performed using total DNA

141 from three male and three female samples. Each PCR reaction were performed in a $20 \mu 1$ volume 142 containing $20 \mathrm{ng}$ of DNA, $4 \mathrm{mM}$ dNTPs, $75 \mathrm{mM} \mathrm{MgCl}$, $3.5 \rho \mathrm{M}$ for each primer and 0.5 unit of

143 Taq polymerase (Vivantis, Malaysia) using 35 cycles of $94^{\circ} \mathrm{C}$ for $30 \mathrm{~s}, 56^{\circ} \mathrm{C}$ for $1.30 \mathrm{~min}$ and

$14472^{\circ} \mathrm{C}$ for $30 \mathrm{~s}$, with a final extension for $5 \mathrm{~min}$. EST-SSR and gSSR microsatellite markers

145 (Table S6 and S7, based on Arabnezhad et al., 2012; Billotte et al., 2004; Elmeer et al., 2011;

146 Pipatchartlearnwong et al., 2017a; Pipatchartlearnwong et al., 2017b) were performed using total

147 DNA from four males and four female samples using the same PCR condition as above. PCR

148 products for RAPD, SCoT and ILP were resolved in $2 \%(\mathrm{w} / \mathrm{v})$ agarose gel electrophoresis and

149 visualized under ultraviolet (UV) light after staining with ethidium bromide. Those for AFLP,

150 SCoT+EST-SSR, SCoT+TEs, EST-SSR and gSSR were resolved in $6 \%(\mathrm{w} / \mathrm{v})$ polyacrylamide

151 gel electrophoresis and visualized by silver staining.

153 Suppression subtractive hybridization (SSH)

154 Total RNA from one male and one female inflorescence samples from Song Khla

155 province were used in the study (Fig. 1G-H). The first-strand and double strand cDNA was

156 synthesized from $1 \mu \mathrm{g}$ of total RNA samples using the SMART cDNA Library Construction Kit

157 (Clontech Laboratories Inc., Palo Alto, CA) following to the manufacturer protocol. Double-

158 strand cDNA of male and female was labeled with biotin-16 dUTP using nick translation: $100 \mu 1$ 
159 total volume containing $400 \mathrm{ng}$ of double-strand cDNA, $3.96 \mathrm{mM}$ of dGTP, dATP and dCTP, 1.6

$160 \mathrm{mM}$ of dTTP, $2.4 \mu 1$ of biotin-16 dUTP (Sigma-Aldrich), $48 \mu \mathrm{M}$ of 5' PCR PrimerII A (5'-

161 AGCAGTGGTATACAACGCAGAGT-3'), 10x Taq buffer, and 5 unit of Taq polymerase

162 (Vivantis, Malaysia) using 40 cycles of $94{ }^{\circ} \mathrm{C}$ for $15 \mathrm{~s}, 65^{\circ} \mathrm{C}$ for $30 \mathrm{~s}$, and $68^{\circ} \mathrm{C}$ for $6 \mathrm{~min}$. The

163 biotin-16 dUTP labeled cDNA was checked for its detection signal using dot blot hybridization

164 at least at $10^{-4}$ dilution. First-strand cDNA of male and female cDNA was subtracted using

165 labeled double-strand cDNA of its opposite sex at ratio 1:3 following a method from Rebrikov et

166 al. (2004). Subtracted samples were purified by ethanol precipitation, and double-strand cDNA

167 was synthesized by PCR reaction containing $2 \mu 1$ of subtracted cDNA, $48 \mu \mathrm{M}$ of 5' PCR

168 PrimerII A, $10 \mathrm{mM}$ dNTPs, 5x NEB polymerase buffer and 5 unit of Q5® High-Fidelity DNA

169 polymerase (New England Biolabs) through 21 cycles of $94{ }^{\circ} \mathrm{C}$ for $15 \mathrm{~s}, 65^{\circ} \mathrm{C}$ for $30 \mathrm{~s}$ and $68^{\circ} \mathrm{C}$

170 for 6 min. Subtracted double-strand cDNA was purified and ligated into pGEM-Teasy

171 (Promega). Clones were selected by blue-white colony section and screened using colony PCR

172 for $>500 \mathrm{bp}$ inserted fragment, before re-selection using dot blot hybridization I and II using

173 probes from opposite sexes. Selected clones were sequenced and analyzed against GenBank

174 using BLAST.

175

\section{Transcriptome analysis}

177 Transcriptome sequencing was performed by Macrogen Inc. (Republic of Korea) using

$17810 \mu \mathrm{g}$ of total RNA. Total RNA was obtained from two male (MY and MO) and two female (FY

179 and FO) inflorescence samples from Nakon-Pathom province (Fig. 1I-J). Briefly, cDNA libraries

180 were constructed using the TruSeq ${ }^{\mathrm{TM}}$ RNA sample preparation kit (Illumina, USA) and

181 sequenced on a HiSeq 2000 (Illumina, USA) with paired-end $100 \mathrm{bp}$ read lengths. Initial raw 
182 reads were trimmed and filtered with FastQC

183 (http://www.bioinformatics.babraham.ac.uk/projects/fastqc) and Trimmomatic version 0.32

184 (http://www.usadellab.org/cms/?page=trimmomatic) software to eliminated low-quality reads

185 (quality score lower than 20) and remove adapters. Reads were considered as high quality if

186 more than $70 \%$ of the bases had Phred values more than Q20. Reads produced from this study

187 were assembled by Trinity software (version r20140717) using default parameters (Grabherr et

188 al., 2011). For similarity search, the assembled transcripts were blasted against the NCBI non-

189 redundant protein sequence database and TAIR database using Blast2GO with the e-value cutoff

$190<10-10$. RSEM version 1.2.15 software was used to estimate transcript abundance (Li \& Dewey,

191 2011). The assembled sequences were analyzed for Gene Ontology (GO) and Kyoto

192 Encyclopedia of Genes and Genomes (KEGG: Kanehisa \& Goto, 2000) using Blast2GO. For

193 differential gene expression analysis, Fastq files were aligned to the assembled transcriptome

194 using TopHat2 alignment program (Kim et al., 2013). Transcriptome annotation file (GFF) was

195 built using the Cufflinks program (Trapnell et al., 2010) by performing a combined assembly of

196 four transcriptome datasets (FY, FO, MY, and MO). Transcript candidates for male and female

197 were chosen using parameters as follows; male-highly represented transcripts [FPKM $>10$ and $>$

1980.5 for MY or MO and FPKM $=0$ for both FY and FO] and [FPKM $>5$ for both MY and MO

199 and FPKM $=0$ for both FY and FO] with length $>300 \mathrm{bp}$, and female-highly represented

200 transcripts $[\mathrm{FPKM}>10$ and $>0.5$ for FY or FO and FPKM $=0$ for both MY and MO] and

$201[\mathrm{FPKM}>5$ for both FY and FO and FPKM $=0$ for both MY and MO] with length $>300$ bp. To

202 identify shared transcripts among the four datasets, transcripts from each dataset with FPKM $>5$

203 and length $>300$ bp were analyzed using Venny version 2.1.0. Identified male and female

204 specific transcripts were subjected to GO enrichment analysis using Fisher's Exact Test with 
205 FDR cutoff $=0.01$. Differentially expressed genes (DEGs) among the four transcript datasets 206 were analyzed by Cuffdiff with FDR cutoff $<0.05$.

207

208

\section{Results}

209

Extensive DNA fingerprinting analysis failed to identify any sex-linked marker for Asian

Palmyra palm in Thailand

211

Previously, George et al. (2007) had developed a RAPD based male-specific marker

$212\left(\mathrm{OPA}-06_{600}\right)$ for the Asian Palmyra palm population in India. Initially, we tested this marker for

213 sex identification in our population in Thailand using up to 20 male and 24 female individuals,

214 but this marker was unable to confirm the sexes (Fig. S1). To identify sex-linked markers for

215 Asian Palmyra palm in Thailand, we generated male and female DNA fingerprints using ten

216 different DNA fingerprinting techniques as presented in Table 1. Although a number of potential

217 sex-linked bands were obtained from SCoTs/EST-SSRs and SCoTs/TEs, after sequencing and

218 re-testing these bands using specific primers, no sex-linked marker was obtained. Despite such

219 extensive screening of DNA markers up to 1,204 primer pairs by the ten techniques, we did not

220 obtain any sex-linked marker. This experiment shows that the DNA fingerprinting covered here

221 is inadequate for identifying a sex-linked marker for Asian Palmyra palm. And, it also suggests

222 that sex determination region in this species could be of small and very difficult to identify.

223 Further attempts for this scheme in the Asian Palmyra palm should be aware of this limitation.

224 Other means of sex identification for Asian Palmyra palm should be explored.

225

226 Identification of sex-related transcripts by SSH analysis using male and female

227 inflorescence flowers 

male and female inflorescences of Asian Palmyra palm. Because the floral development of this species is not well defined, we collected young inflorescence stems from male and female plants as soon as they emerged from the dense leaf sheets and isolated young floral tissues for RNA

232 isolation. Female flower buds ( $\sim 2 \mathrm{~cm}$ in diameter) were removed from the inflorescence (Fig.

233 1G), while the male inflorescences ( $\sim 9 \mathrm{~cm}$ in length) were used as a whole (Fig. 1H). Direct

234 cloning of subtracted-cDNA yielded 2,574 and 9,820 clones for male and female, respectively,

235 and, after colony-PCR screening for $>500$ bp inserted-fragments, we obtained 1,288 and 4,097

236 clones for male and female libraries, respectively (Table 2). These selected clones were re-tested

237 against their opposite sex using two rounds of dot blot hybridization (I and II), resulting in 81

238 and 63 clones for male- and female-specific libraries, respectively. These clones were

239 subsequently sequenced and searched in GenBank using BLASTX, and 60 male and 29 female

240 clones were found matching to non-redundant genes in the plant database (Table S8). These

241 sequences have been deposited in GenBank (JZ977504-JZ977592) as ESTs for male or female

242 inflorescence flowers of Asian Palmyra palm.

243 Among the total 99 identified clones, 91 and 98 clones share high similarities to

244 sequences in the nuclear genome of date palm and oil palm, respectively. As oil palm has both

245 male and female genome sequences available, we observed that all 99 sequences identified in

246 Asian Palmyra palm are present in both male and female genomes of oil palm, suggesting that

247 these sequences could not be used as sex-specific markers. Nonetheless, we tested 19 selected

248 sequences on gDNA from male and female plants by PCR using specific primers (Table S9), and

249 these failed to identify the sexes. Although this experiment was unable to provide a sex-linked 
250 marker, the list of expressed genes during male- and female-floral development of Asian

251 Palmyra palm could be of use for future study.

252

253 De novo transcriptome sequencing of male and female inflorescences

254 To further identify sex-related genes for sex identification, we performed de novo

255 transcriptome sequencing using RNA from male and female inflorescences. Four cDNA libraries

256 were constructed from two floral stages of male and female (FY-female young inflorescences,

257 FO-female old inflorescences, MY-male young inflorescences and MO-male old inflorescences;

258 Fig. 1I-J), which were in earlier stages than those used in the SSH experiment. From Illumina

259 HiSeq2000 sequencing, we obtained 47,194,682-90,305,610 reads for each sample with an

260 average length of $98 \mathrm{bp}$, after trimming the adapter sequences and removing low-quality

261 nucleotides $(<\mathrm{Q} 20)$ and short sequences $(<25 \mathrm{nt})$ (Fig. 2). Sequence assembly using Trinity

262 yielded 187,083 transcripts with $705 \mathrm{bp}$ average length. Most of the assembled transcripts were

263 between 200 and $300 \mathrm{bp}$ in length, and up to 70,785 transcripts were $>500$ bp in length (Fig. $2 \mathrm{~b}$ ).

264 The transcripts were annotated by using BLASTX searches against the NCBI non-redundant

265 protein database, and 77,578 transcripts ( $41.47 \%$ of initial transcripts) were identified as unique

266 sequences with significant similarities $(\mathrm{E}<1 \mathrm{e}-10)$ to known protein sequences from 5,331

267 different species. The average alignment length (\%) matched was $81.3 \%$ with the highest

268 positive matched per alignment length being $90 \%$, and the average percent identity was $81.24 \%$.

269 Most of these sequences were identified as similar sequences to those found in date palm (53\%)

270 and oil palm (37\%) (Fig. 2C). The Transcriptome Shotgun Assembly are deposited at

271 DDBJ/ENA/GenBank under the accession GFYQ00000000.

272 


\section{GO classification and pathway assignment by KEGG}

274 Gene ontology (GO) terms of the 77,578 annotated transcripts were assigned using

275 Blast2GO program in three categories: biological process, cellular component and molecular

276 function. The transcripts were assigned into 66 functional groups, and top GO terms with more

277 than $1 \%$ assigned transcripts in each category are presented in Fig. S2. Binding and catalytic

278 activity were dominant in the molecular function category, while the integral component of the

279 membrane and nucleus dominated the cellular component category. For the biological process,

280 oxidation-reduction process and protein phosphorylation were the most represented groups.

281 Subsequently, function classification and pathway assignments based on Kyoto Encyclopedia of

282 Genes and Genomes (KEGG) showed that, among the 77,578 annotated transcripts, 16,635 were

283 annotated with enzyme code EC numbers and mapped into 139 KEGG pathways. Pathways with

284 more than 1\% matched transcripts are presented in Fig. S3. Purine (map00230) and Thymine

285 (map00730) metabolisms were the most matched pathways with 4,913 transcripts (18.89\%) and

286 2,581 transcripts (9.92\%), followed by Biosynthesis of antibiotics (map01130) with 1,582

287 transcripts (6.08\%). Interestingly, starch and sucrose metabolism (map00500) presented at the

288 fourth rank with 1,187 transcripts (4.56\%). Transcripts mapped into this pathway were mostly

289 related to sugar metabolism for fructose and sucrose production, but less supported to starch

290 biosynthesis (Fig. 3 and Table 3; see the transcript IDs in Table S10). Other related sugar

291 metabolic pathways were also found among the list of top pathways including $1.54 \%$ of

292 glycolysis/gluconeogenesis (map00010), 1.25\% of pentose and glucuronate interconversions

293 (map00040), 1.19\% of Galactose metabolism (map00052), 1.10\% of fructose and mannose

294 metabolism (map00051), $0.87 \%$ of pentose phosphate pathway (map00030) and $0.85 \%$ of

295 inositol phosphate metabolism (map00562). This observation coincides with the facts that both 
296 male and female inflorescences of Asian Palmyra palm produce sweet sap, which has been used

297 for making palm sugar for centuries.

298

299 Differential expression of genes between male and female inflorescences

Among the initial 187,083 transcripts, we observed a number of transcripts that were

301 highly represented in either male or female datasets, but none in their opposite sex $(\mathrm{FPKM}=0)$;

30233 and 11 transcripts were identified from female and male datasets, respectively (length $>300$

303 bp, FPKM $>5$ for both FY and FO or MY and MO, and FPKM $>10$ and $>0.5$ for FY or FO and

304 MY or MO) (Table S11). Although annotations of these transcripts did not show any evidence

305 related to genes for male- or female-specific development, we observed four cell wall-related

306 transcripts in the female datasets, and this may reflect that the developing female flower

307 undergoes rapid and extensive organ enlargement, whereas the male flower is limited to a small

308 size. Because the genome sequence of Asian Palmyra palm is currently unavailable, we thus

309 tested whether these transcripts could be used for sex identification by PCR using male and

310 female gDNA and primers specific to these 44 transcript sequences (Table S12). However, these

311 primers gave similar band patterns between male and female gDNA (Fig. S4), indicating that

312 these primers cannot be used for identifying the sexes.

313 By comparing the transcripts among the four datasets (length $>300$ bp and FPKM $>5$ ),

314 we found that 17,231 transcripts were shared among all datasets, and 4,514 (14.4\%) and 3,312

$315(10.5 \%)$ transcripts were identified as male- and female-specific transcripts, respectively (Fig. 4

316 and Table S13). These transcripts were further classified into specific MY (2,192 transcripts),

317 MO (1,405 transcripts), FY (1,355 transcripts) and FO (1,165 transcripts) to identify transcripts

318 that may relate to male or female floral development stages. Subsequently, we analyzed enriched 
319 GO terms for the male- and female-specific datasets (length $>300$ bp and FPKM $>5$ ), and top

320 enriched GO terms (FDR < 1E-02) are presented in Table 4 (see Table S14 for transcript IDs).

321 All GO terms observed here were over-represented compared to the reference sets. Interestingly,

322 carbohydrate metabolism and cell wall-related processes were much apparent in the female-

323 specific transcripts, while various catabolic processes for biological compounds dominated the

324 male-specific transcripts.

325 In light of this transcriptome analysis, we cross-referenced the 60 male and 29 female-

326 specific clones from the SSH experiment to the transcript abundance data. Noting that RNA

327 samples used in the SSH experiment were obtained from an older inflorescence stage than those

328 used for transcriptome analysis. The transcript IDs were readily identified with more than $90 \%$

329 identical matches and $>300$ transcript length (Table S15). However, we found that, based on

330 FPKM values, the sex-specific clones were indeed uncorrelated to almost all of the transcript

331 data, and only F152 (predicted proline-rich protein 4-like) clone could be identified for their

332 expression towards the female. Though, this clone has no direct relationship to sex development

333 based on the annotation.

334 To further verify sex-related genes, we analyzed differentially expressed genes among the

335 four datasets by using Cuffdiff with FDR $<0.05$ cutoff. Initially, 816 transcripts were identified,

336 but only 43 transcripts displayed differential expression between sexes with transcript length $>$

337300 bp, FPKM $>5$, GO terms and significant q value $(<0.05)$ (Table 5). Among these 43

338 transcripts, seven transcripts were annotated with genes previously identified to be involved in

339 sex determination and flower development: two and five transcripts for female and male datasets,

340 respectively. Furthermore, we observed six and one transcripts encoding transcription factors

341 that were highly expressed in female and male datasets, respectively. Although being identified 
342 for differential expression between the sexes, c1819_g1_i1 and c142400_g1_i1 transcripts

343 encoding ethylene-responsive transcription factors were highly expressed throughout the four

344 datasets, and these genes may be required for the floral development. List of gene candidates

345 indicated here could be used for a further study on sex determination and floral development in

346 Asian Palmyra palm and other related palm species.

347

348 Discussion

349 Previously, there were only two reports that attempted to develop sex identification

350 markers in Asian Palmyra palm. George et al. (2007) presented a male-specific OPA-06 600

351 marker after screening 180 RAPD primers using ten male and ten female samples from several

352 populations in India and later used this marker to verify the sexes of more than 100 seedlings

353 (George \& Karun, 2011). Vinayagam et al. (2009) reported another attempt, but could not

354 identify any sex-linked marker after screening up to 130 ISSR markers (with 65 polymorphic

355 bands) based on 20 accessions from another population in India. In this work, we have also

356 tested the OPA- $06_{600}$ marker in Thailand populations, which were collected from the central,

357 northeastern and southern regions, but this marker failed to confirm the sexes in our experiment.

358 The limitation of sex-linked markers across varieties and populations is common (Heikrujam et

$359 a l ., 2015)$, and it is most likely due to sequence variation at loci used for developing the markers.

360 Thus, it is required that sex-linked markers for populations in Thailand have to be specifically

361 developed.

362 The success of identifying molecular markers via DNA fingerprinting may lie upon the

363 genome size and the number of screening PCR primers, and this has been reflected in many

364 reports for developing sex-linked markers (see Heikrujam et al., 2015 for an extensive review on 
365 the numbers of primers used in different dioecious plants). Surprisingly, date palm, which is

366 closely related to Asian Palmyra palm (Barrett et al., 2016; Sakulsathaporn et al., 2017), readily

367 yielded sex-linked markers when tested with only small numbers of screening primers. For

368 example, Younis, Ismail \& Soliman (2008) obtained one male-specific and two female-specific

369 markers after screening 30 RAPD primers and five male-specific markers after screening 20

370 ISSR primers, Elmeer \& Mattat (2012) identified 22 microsatellite loci for sex-determination in

371 some date palm cultivars after screening 14 SSR primer pairs, and Dhawan et al. (2013)

372 identified a male-specific marker after screening 100 RAPD primers. Because the genome size of

373 Asian Palmyra palm has not yet been reported, it is difficult to estimate the number of screening

374 primers to cover the genome for effective screening. Considering our experiment using an

375 extensive set of 1,204 primer pairs among ten techniques and there was only a single sex-linked

376 marker identified in the previous attempts using up to 180 RAPD and 130 SSR primers

377 (Vinayagam et al., 2009; George \& Karun 2011), this demonstrated a complexity in identifying 378 sex-linked loci in Asian Palmyra palm.

379 Sex identification of date palm was subjected to a debate as newly developed sex-linked

380 markers via DNA fingerprinting often failed when tested in other varieties or populations (Rania

381 et al., 2008; Al-Mahmoud et al., 2012; Elmeer \& Mattat, 2012; Dhawan et al., 2013; Maryam et

382 al., 2016). Indeed, varieties of date palm germplasm and geographical populations were included

383 as much when developing those markers, but the power of sex identification was limited by the

384 variation of DNA sequences at the sex loci and, at that time, an unclear sex determination system

385 in date palm. This problem has recently been solved by the availability of date palm genomes

386 (Al-Dous et al., 2011), verification of sex determination loci (Cherif et al., 2013) and

387 construction of genetic map (Mathew et al., 2014), validating that date palm has a homomorphic 
388 XY chromosome system. This sex chromosome is currently being used to develop precise sex-

389 specific markers for specific varieties and populations of date palm (Mohei et al., 2017; Ali et

390 al., 2018; Intha \& Chaiprasart, 2018). Thus, it is potential that genome sequencing of Asian

391 Palmyra palm could help us verify the sex determination region and, perhaps, the sex

392 determination system in Asian Palmyra palm.

393 Potential sex-specific transcripts of Asian Palmyra palm were identified from SSH and de

394 novo transcriptome analyses. We have tested many of these sex-specific transcripts for

395 developing sex identification markers by PCR analysis, but none was achieved. Based on a

396 chromosome study by Sharma \& Sarkar (1956) proposing the XY chromosomes as the sex

397 determination system of Asian Palmyra palm (XY for male and XX for female), it can be

398 anticipated that transcripts from X chromosome should be detected in both sexes, while

399 transcripts from the male-specific region of the Y chromosome should only be found in the male.

400 Although most male-specific transcripts identified here are expected to be autosomal genes that

401 support anther development or female sterility, some will be encoded by genes on the male

402 specific region of the Y chromosome (MSY). Those male-specific transcripts can be used as

403 markers for sex and are candidates for sex determination genes. However, PCR analysis of male-

404 specific transcripts so far could not identify any male-specific marker. Studying Y chromosome

405 of Asian Palmyra palm would be essential for further development on male-specific markers.

406 Through the exhaustive screening of sex-specific markers using the three approaches

407 performed in this work, this may reveal some aspects of the sex chromosome evolution of this

408 palm species. Firstly, it is possible that the Asian Palmyra palm may have evolutionary young

409 sex chromosomes, which recently diverged, and that the MSY is too small to be identified by the

410 scope of this work. It could be interesting to add Asian Palmyra palm as a specimen for studying 
411 the evolution of sex chromosomes (Charlesworth, 2015). Secondly, although the work by

412 Sharma \& Sarkar (1956) had depicted clearly large difference of the sex chromosomes in the

413 shape and size, it is still uncertain whether the XY chromosomes is the sex determination system

414 of this palm as it has not been confirmed at molecular levels. Thirdly, because George et al.,

415 (2007) had identified a male-specific marker, which could not be used in the palm population in

416 Thailand, there may be a unique haplotype of the MSY in Thailand. This haplotype may arise

417 from selected individuals during migration to the southeast Asia (Pipatchartlearnwong et al.,

418 2017a) or the sex chromosomes were recently evolved with small sex determination regions that

419 are difficult to detect.

420 By comparing the SSH and transcriptome data, to our surprise, most SSH clones were

421 uncorrelated to the sexes, given that the cDNA clones were screened through two rounds of dot

422 blot hybridization. This observation may indicate the limitation of the SSH technique for

423 identifying genes in a complex system. Alternatively, this may be because the RNA samples

424 used for the SSH analysis were obtained from different flower stages from those used for the

425 transcriptome sequencing. A potential weakness of the SSH and transcriptome sequencing was

426 that RNA samples were isolated from developing inflorescence tissues, not from inflorescence

427 primordia that initiate sex organs and that key sex determination transcripts may not be present

428 or difficult to identify in the inflorescence stages (Harkess et al., 2015). Collecting the primordial

429 tissues for this study is a very challenging task, as the Asian Palmyra palm tip is covered by

430 many layers of thick and hard leaf sheets standing at 20 meters height with no indication whether

431 the primordial tissues will develop to be an inflorescence or a leaf, and the plant usually dies

432 after tip removal. Moreover, the variation of sequencing depth among the samples (47-90 million 
433 reads per sample) and the lack of replicates could attribute to the complication for extracting

434 robust conclusions from the transcriptome analysis.

435 Nonetheless, this work provides transcriptome data that would particularly benefit to two

436 research areas: plant sucrose metabolism and sex development in palms and monocots. Sucrose

437 production is one of the important areas in plant biotechnology, and many transcriptome studies

438 have devoted to understand the control of metabolic flux towards sucrose. Most of the study was

439 performed in major sugar crops including sugarcane (Cardoso-Silva et al., 2014; Huang et al.,

440 2016), sugar beets (Mutasa-Göttgens et al., 2012) and sorghum (Mizuno, Kasuga \&

441 Kawahigashi, 2016), and our data add transcript candidates for sucrose metabolism in the

442 inflorescence of palm species. For sex development, male- and female-specific transcripts and

443 differentially expressed transcripts between sexes were listed to provide data for further study in

444 sex determination and male and female inflorescence development. A number of studies with

445 similar objectives in identifying sex determination genes and underlying mechanisms of sex

446 development in dioecious plants via the transcriptome sequencing have been reported in

447 asparagus (Harkess et al., 2015; Li et al., 2017), Idesia polycarpa (Mei et al., 2017), shrub

448 willows (Salix suchowensis) (Liu et al., 2013), poplar (Song et al., 2013) and Coccinia grandis

449 (Mohanty et al., 2017). Most of the identified genes belong to floral development, phytohormone

450 biosynthesis, hormone signaling and transduction, transcriptional regulation and DNA

451 methyltransferase activity. However, with many genes playing the role during the complex

452 developmental process, it is difficult to determine the mechanism underlying the sexual

453 development and sex determination in dioecious species. Future progress in functional genomic

454 addressing the identified genes would be an essential tool to solve this long-standing question. 
456

\section{Conclusions}

Although no sex-linked marker was obtained from exhaustive DNA fingerprinting, SSH and de novo transcriptome analysis, this work provides transcripts based on male and female inflorescences of the Asian Palmyra palm. Further attempts on developing sex identification markers in Asian Palmyra palm should be directed towards genomic-based approaches, particularly at the MSY. Genome analysis using SNPs have been successful in accessing sex determination loci in date palm (Al-Mahmoud et al., 2012; Ali et al., 2018) and other dioecious plant species (Jia et al., 2018; Zhou et al., 2018). Whole genome sequencing, genetic map, SNPs and genome-wide association study (GWAS) between male and female populations would be essential tools for further identification of sex-linked loci in Asian Palmyra palm.

\section{References}

Al-Dous, E.K., George, B., Al-Mahmoud, M.E., Al-Jaber, M.Y., Wang, H., Salameh, Y.M., AlAzwani, E.K., Chaluvadi, S., Pontaroli, A.C., DeBarry, J. and Arondel, V., 2011. De novo genome sequencing and comparative genomics of date palm (Phoenix dactylifera). Nature biotechnology, 29(6), p.521.

Al-Mahmoud, M.E., Al-Dous, E.K., Al-Azwani, E.K. and Malek, J.A., 2012. DNA-based assays to distinguish date palm (Arecaceae) gender. American journal of botany, 99(1), pp.e7-e10.

Ali, H.B.M., Abubakari, A., Wiehle, M. and Krutovsky, K.V., 2018. Gene-specific sex-linked genetic markers in date palm (Phoenix dactylifera L.). Genetic Resources and Crop Evolution, 65(1), pp.1-10. 
477 478

Arabnezhad, H., Bahar, M., Mohammadi, H.R. and Latifian, M., 2012. Development, characterization and use of microsatellite markers for germplasm analysis in date palm (Phoenix dactylifera L.). Scientia Horticulturae, 134, pp.150-156.

Barfod, A.S., Balhara, M., Dransfield, J. and Balslev, H., 2015. SE Asian palms for agroforestry and home gardens. Forests, 6(12), pp.4607-4616.

Barrett, C.F., Baker, W.J., Comer, J.R., Conran, J.G., Lahmeyer, S.C., Leebens-Mack, J.H., Li, J., Lim, G.S., Mayfield-Jones, D.R., Perez, L. and Medina, J., 2016. Plastid genomes reveal support for deep phylogenetic relationships and extensive rate variation among palms and other commelinid monocots. New Phytologist, 209(2), pp.855-870.

Beck, H.T. and Balick, M.J., 1990. Useful palms of the world.

Billotte, N., Marseillac, N., Brottier, P., Noyer, J.L., Jacquemoud-Collet, J.P., Moreau, C., Couvreur, T., Chevallier, M.H., Pintaud, J.C. and Risterucci, A.M., 2004. Nuclear microsatellite markers for the date palm (Phoenix dactylifera L.): characterization and utility across the genus Phoenix and in other palm genera. Molecular Ecology Notes, 4(2), pp. $256-258$.

Blázquez, M.A., Soowal, L.N., Lee, I. and Weigel, D., 1997. LEAFY expression and flower initiation in Arabidopsis. Development, 124(19), pp.3835-3844.

Bureau, T.E. and Wessler, S.R., 1994. Mobile inverted-repeat elements of the Tourist family are associated with the genes of many cereal grasses. Proceedings of the National Academy of Sciences, 91(4), pp.1411-1415.

Cao, D., Cheng, H., Wu, W., Soo, H.M. and Peng, J., 2006. Gibberellin mobilizes distinct DELLA-dependent transcriptomes to regulate seed germination and floral development in Arabidopsis. Plant physiology, 142(2), pp.509-525. 
500 Cardoso-Silva, C.B., Costa, E.A., Mancini, M.C., Balsalobre, T.W.A., Canesin, L.E.C., Pinto,

501 L.R., Carneiro, M.S., Garcia, A.A.F., de Souza, A.P. and Vicentini, R., 2014. De novo

502 assembly and transcriptome analysis of contrasting sugarcane varieties. PloS one, 9(2),

503 p.e88462.

504 Charlesworth, D., 2015. Plant contributions to our understanding of sex chromosome

$505 \quad$ evolution. New Phytologist, 208(1), pp.52-65.

506 Cherif, E., Zehdi, S., Castillo, K., Chabrillange, N., Abdoulkader, S., Pintaud, J.C., Santoni, S.,

507 Salhi-Hannachi, A., Glémin, S. and Aberlenc-Bertossi, F., 2013. Male-specific DNA

508 markers provide genetic evidence of an XY chromosome system, a recombination arrest

509 and allow the tracing of paternal lineages in date palm. New Phytologist, 197(2), pp.409-

$510 \quad 415$.

511 Collard, B.C. and Mackill, D.J., 2009. Start codon targeted (SCoT) polymorphism: a simple,

512 novel DNA marker technique for generating gene-targeted markers in plants. Plant

513 molecular biology reporter, 27(1), p.86.

514 Davis, T.A. and Johnson, D.V., 1987. Current utilization and further development of the palmyra

515 palm (Borassus flabellifer L., Arecaceae) in Tamil Nadu State, India. Economic

$516 \quad$ Botany, 41(2), pp.247-266.

517 Dhawan, C., Kharb, P., Sharma, R., Uppal, S. and Aggarwal, R.K., 2013. Development of male-

518 specific SCAR marker in date palm (Phoenix dactylifera L.). Tree genetics \&

519 genomes, $9(5)$, pp.1143-1150.

520 Dransfield, J., Uhl, N.W., Asmussen, C.B., Baker, W.J., Harley, M.M. and Lewis, C.E., 2005. A new phylogenetic classification of the palm family, Arecaceae. Kew Bulletin, pp.559-569. 
522 Elmeer, K. and Mattat, I., 2012. Marker-assisted sex differentiation in date palm using simple 523 sequence repeats. 3 Biotech, 2(3), pp.241-247.

524 Elmeer, K., Sarwath, H., Malek, J., Baum, M. and Hamwieh, A., 2011. New microsatellite 525 markers for assessment of genetic diversity in date palm. Phoenix dactylifera, pp.91-97.

526 Fan, Y., Yu, M., Liu, M., Zhang, R., Sun, W., Qian, M., Duan, H., Chang, W., Ma, J., Qu, C. and Zhang, K., 2017. Genome-wide identification, evolutionary and expression analyses of the GALACTINOL SYNTHASE gene family in rapeseed and tobacco. International journal of molecular sciences, 18(12), p.2768.

530 Ferguson, W., 1850. Description of the Palmyra palm of Ceylon.

531 Fox, J.J., 1977. Harvest of the palm. Ecological change in eastern Indonesia. Harvard Univ.

532 Press.

533 George, J. and Karun, A., 2011. Marker assisted detection of seed sex ratio in palmyrah palm $534 \quad$ (Borassus flabellifer L.). Current Science, pp.922-925.

535 George, J., Karun, A., Manimekalai, R., Rajesh, M.K. and Remya, P., 2007. Identification of 536 RAPD markers linked to sex determination in palmyrah (Borassus flabellifer L.). Current science, 93(8), pp.1075-1077.

538 Grabherr, M.G., Haas, B.J., Yassour, M., Levin, J.Z., Thompson, D.A., Amit, I., Adiconis, X.,

539 Fan, L., Raychowdhury, R., Zeng, Q. and Chen, Z., 2011. Full-length transcriptome 540 assembly from RNA-Seq data without a reference genome. Nature biotechnology, 29(7), $541 \quad$ p.644.

542 Harkess, A., Mercati, F., Shan, H.Y., Sunseri, F., Falavigna, A. and Leebens-Mack, J., 2015.

543 Sex-biased gene expression in dioecious garden asparagus (Asparagus officinalis). New $544 \quad$ Phytologist, 207(3), pp.883-892. 
545 Heikrujam, M., Sharma, K., Prasad, M. and Agrawal, V., 2015. Review on different mechanisms

546 of sex determination and sex-linked molecular markers in dioecious crops: a current

$547 \quad$ update. Euphytica, 201(2), pp.161-194.

548 Huang, D.L., Gao, Y.J., Gui, Y.Y., Chen, Z.L., Qin, C.X., Wang, M., Liao, Q., Yang, L.T. and

549 Li, Y.R., 2016. Transcriptome of High-sucrose sugarcane variety GT35. Sugar Tech, 18(5),

$550 \quad$ pp.520-528.

551 Intha, N. and Chaiprasart, P., 2018. Sex determination in date palm (Phoenix dactylifera L.) by

$552 \quad$ PCR based marker analysis. Scientia Horticulturae, 236, pp.251-255.

553 Kanehisa, M. and Goto, S., 2000. KEGG: kyoto encyclopedia of genes and genomes. Nucleic

554 acids research, 28(1), pp.27-30.

555 Kim, D., Pertea, G., Trapnell, C., Pimentel, H., Kelley, R. and Salzberg, S.L., 2013. TopHat2:

556 accurate alignment of transcriptomes in the presence of insertions, deletions and gene

557 fusions. Genome biology, 14(4), p.R36.

558 Kovoor, A., 1983. The palmyrah palm: potential and perspectives (No. 52).

559 Li, B. and Dewey, C.N., 2011. RSEM: accurate transcript quantification from RNA-Seq data

560 with or without a reference genome. BMC bioinformatics, 12(1), p.323.

561 Li, S.F., Zhang, G.J., Zhang, X.J., Yuan, J.H., Deng, C.L. and Gao, W.J., 2017. Comparative

562 transcriptome analysis reveals differentially expressed genes associated with sex

563 expression in garden asparagus (Asparagus officinalis). BMC plant biology, 17(1), p.143.

564 Lim, T.K., 2012. Edible medicinal and non-medicinal plants (Vol. 1, pp. 656-687). Dordrecht:

$565 \quad$ Springer.

566 Liu, S., Xu, L., Jia, Z., Xu, Y., Yang, Q., Fei, Z., Lu, X., Chen, H. and Huang, S., 2008. Genetic association of ETHYLENE-INSENSITIVE3-like sequence with the sex-determining M 
locus in cucumber (Cucumis sativus L.). Theoretical and applied genetics, 117(6), pp.927933.

570 Liu, J., Yin, T., Ye, N., Chen, Y., Yin, T., Liu, M. and Hassani, D., 2013. Transcriptome analysis of the differentially expressed genes in the male and female shrub willows (Salix suchowensis). PloS one, 8(4), p.e60181.

573

Maryam, J.M., Awan, F.S., Ahmad, S. and Khan, I.A., 2016. Development of molecular method for sex identification in date palm. Phoenix dactylifera, pp.1-7.

Mathew, L.S., Spannagl, M., Al-Malki, A., George, B., Torres, M.F., Al-Dous, E.K., Al-Azwani, E.K., Hussein, E., Mathew, S., Mayer, K.F. and Mohamoud, Y.A., 2014. A first genetic map of date palm (Phoenix dactylifera) reveals long-range genome structure conservation in the palms. BMC genomics, 15(1), p.285.

Mei, L., Dong, N., Li, F., Li, N., Yao, M., Chen, F. and Tang, L., 2017. Transcriptome analysis of female and male flower buds of Idesia polycarpa Maxim. var. vestita Diels. Electronic Journal of Biotechnology, 29, pp.39-46.

Mizuno, H., Kasuga, S. and Kawahigashi, H., 2016. The sorghum SWEET gene family: stem sucrose accumulation as revealed through transcriptome profiling. Biotechnology for biofuels, $9(1)$, p.127.

Mohanty, J.N., Nayak, S., Jha, S. and Joshi, R.K., 2017. Transcriptome profiling of the floral buds and discovery of genes related to sex-differentiation in the dioecious cucurbit Coccinia grandis (L.) Voigt. Gene, 626, pp.395-406.

Mohei, E.L., Mohasseb, H.A.A., Al-Khateeb, A.A., Al-Khateeb, S.A., Chowdhury, K., ElShemy, H.A. and Aldaej, M.I., 2017. Identification and sequencing of Date-SRY Gene: A 
novel tool for sex determination of date palm (Phoenix dactylifera L.). Saudi Journal of

591 Biological Sciences. doi.org/10.1016/j.sjbs.2017.08.002

592 Morton, J.F., 1988. Notes on distribution, propagation, and products of Borassus Palms

593 (Arecaceae). Economic botany, 42(3), pp.420-441.

594 Mutasa-Göttgens, E.S., Joshi, A., Holmes, H.F., Hedden, P. and Göttgens, B., 2012. A new

595 RNASeq-based reference transcriptome for sugar beet and its application in transcriptome-

596 scale analysis of vernalization and gibberellin responses. BMC genomics, 13(1), p.99.

597 Nagai, J.I., Yamato, K.T., Sakaida, M., Yoda, H., Fukuzawa, H. and Ohyama, K., 1999.

598 Expressed sequence tags from immature female sexual organ of a liverwort, Marchantia

599 polymorpha. DNA Research, 6(1), pp.1-11.

600 Nonomura, K.I., Morohoshi, A., Nakano, M., Eiguchi, M., Miyao, A., Hirochika, H. and Kurata,

601 N., 2007. A germ cell-specific gene of the ARGONAUTE family is essential for the

602 progression of premeiotic mitosis and meiosis during sporogenesis in rice. The Plant

603 Cell, 19(8), pp.2583-2594.

604 Pipatchartlearnwong, K., Swatdipong, A., Vuttipongchaikij, S. and Apisitwanich, S., 2017a.

605 Genetic evidence of multiple invasions and a small number of founders of Asian Palmyra

606 palm (Borassus flabellifer) in Thailand. BMC genetics, 18(1), p.88.

607 Pipatchartlearnwong, K., Swatdipong, A., Vuttipongchaikij, S. and Apisitwanich, S., $2017 \mathrm{~b}$.

608 Cross-genera transferability of microsatellite loci for Asian Palmyra Palm (Borassus

609 flabellifer L.). HortScience, 52(9), pp.1164-1167.

610 Rania, A.A. and Younis, O., 2008. Identifica tion of Sex Specific DNA Markers for Date Palm

611 (Phoenix dactylifera L.) Using RAPD and ISSR. Tech. Res. J. Agric. Biol. Sci, 4(4),

$612 \quad$ pp.278-284. 
613 Rebrikov, D.V., Desai, S.M., Siebert, P.D. and Lukyanov, S.A., 2004. Suppression subtractive 614 hybridization. In Gene expression profiling (pp. 107-134). Humana press.

615 Sakulsathaporn, A., Wonnapinij, P., Vuttipongchaikij, S. and Apisitwanich, S., 2017. The 616 complete chloroplast genome sequence of Asian Palmyra palm (Borassus flabellifer). BMC 617 research notes, $10(1)$, p.740.

618 Sharma, A.K. and Sarkar, S.K., 1956. Veratrine: Its use in Cytochemistry: (with Plate 619 XIX). Caryologia, 8(2), pp.240-249.

620 Sirajuddin, S., Mulyadi, M., Dirawan, G.D., Amir, F. and Pertiwi, N., 2016. Conservation status 621 of lontar palm trees (Borassus flabellifer Linn) in Jeneponto district, South Sulawesi, 622 Indonesia. Journal of Tropical Crop Science, 3(1).

623 Song, Y., Ma, K., Ci, D., Chen, Q., Tian, J. and Zhang, D., 2013. Sexual dimorphic floral 624 development in dioecious plants revealed by transcriptome, phytohormone, and DNA 625 methylation analysis in Populus tomentosa. Plant molecular biology, 83(6), pp.559-576.

626 Takata, M., Kishima, Y. and Sano, Y., 2005. DNA methylation polymorphisms in rice and wild 627 rice strains: detection of epigenetic markers. Breeding Science, 55(1), pp.57-63.

628 Tao, Q., Niu, H., Wang, Z., Zhang, W., Wang, H., Wang, S., Zhang, X. and Li, Z., 2018.

629 Ethylene responsive factor ERF110 mediates ethylene-regulated transcription of a sex 630 determination-related orthologous gene in two Cucumis species. Journal of experimental $631 \quad$ botany, 69(12), pp.2953-2965.

632 Trapnell, C., Williams, B.A., Pertea, G., Mortazavi, A., Kwan, G., Van Baren, M.J., Salzberg, 633 S.L., Wold, B.J. and Pachter, L., 2010. Transcript assembly and quantification by RNA634 Seq reveals unannotated transcripts and isoform switching during cell 635 differentiation. Nature biotechnology, 28(5), p.511. 
636 Ukoskit, K. and U-thoomporn, S. 2016. Development of ILP markers from genes involving in oil 637 palm (Elaeis guineensis Jacq.) inflorescence. Thai Science and Technology Journal, 24, pp. $638 \quad 299-308$. DOI 10.14456/tstj.2016.23

639 Vinayagam, P., Dhandapani, J., Raman, P., Alagarsamy, R.K., Muthusamy, P. and Balaraman, 640 S.S., 2009. Molecular characterization for genetic diversity of Palmyrah (Borassus 641 flabellifer) accessions using inter simple sequence repeat (ISSR) markers. Asian Australas $642 \quad J$ plant Sci. Biotechnol, 3(1), pp.11-5.

643 Younis, R.A., Ismail, O.M. and Soliman, S.S., 2008. Identification of sex-specific DNA markers 644 for date palm (Phoenix dactylifera L.) using RAPD and ISSR techniques. Research 645 Journal of Agriculture and Biological Sciences, 4(4), pp.278-284.

646 


\section{Figure legends}

648 Fig. 1. Asian Palmyra palm samples from male and female plants. (A) A mature male plant with 649 a fully developed male inflorescence and (B) a mature female plant with a female inflorescence 650 bearing fruits. (C) and (D) Representatives of developing male inflorescences from young to 651 mature stages. (E) Representatives of developing female inflorescences, and (F) buds extracted 652 from female inflorescences. (G-J) Representative female and male inflorescence samples used

653 for the SSH experiment ( $\mathrm{G}$ and $\mathrm{H}$, respectively) and de novo transcriptome sequencing analysis 654 (I and J, respectively). Scale bars are indicated within.

655 Fig. 2. De novo transcriptome sequencing overview. (A) total sequence reads (bp) after trimming 656 and removing low quality read $(<$ Q20) of four samples. (B) Distribution of number and length 657 of assembled transcripts, and (C) sequence similarity of assembled transcripts to other plant 658 species.

659 Fig. 3. Mapping of assembled transcripts onto the starch and sucrose metabolism (map00500)

660 taken from KEGG. Mapped enzymes are indicated by colors (see Table S10 for details).

661 Kanehisa Laboratories 00500 5/9/16.

662 Fig. 4. A Venn diagram of four transcript datasets. Numbers and percentages of transcripts are 663 indicated. 


\section{Supplemental Figs and Tables}

665 Supplemental Fig. S1. PCR analysis of 20 male and 23 female Asian Palmyra palm samples

666 using OPA-06 600 RAPD marker. The 600 bp ladder indicate an expected band for the male-

667 specific marker.

668 Supplemental Fig. S2. GO terms of assembled transcripts

669 Supplemental Fig. S3. KEGG and EC numbers of assembled transcripts

670 Supplemental Fig. S4. PCR analysis on gDNA based on male- and female-highly represent

671 transcripts.

672 Supplemental Table S1. AFLP primers.

673 Supplemental Table S2. SCoT primers.

674 Supplemental Table S3. TE primers.

675 Supplemental Table S4. EST-SSR primers from oil palm.

676 Supplemental Table S5. ILP primers.

677 Supplemental Table S6. SSR primers from oil palm. Ta for all primer pairs was $55^{\circ} \mathrm{C}$.

678 Supplemental Table S7. SSR primers from date palm.

679 Supplemental Table S8. Selected SSH clones. F and M represent clones from female and male, 680 respectively.

681 Supplemental Table S9. SSH clone based primers for PCR analysis of gDNA from males and 682 females.

683 Supplemental Table S10. Transcript IDs of starch and sucrose metabolism (KEGG map00500).

684 Supplemental Table S11. Transcript IDs of male- and female-highly represented transcripts.

685 Supplemental Table S12. PCR primers for testing male- and female- highly represented 686 transcripts. 
687 Supplemental Table S13. Transcript IDs categorized based on Venn diagram among the four 688 transcripts datasets.

689 Supplemental Table S14. Transcript IDS of enriched GO of male- and female-specific

690 transcripts.

691 Supplemental Table S15. Comparison between SSH clones and corresponding transcripts from 692 transcriptome sequencing data. 


\section{Table 1 (on next page)}

Total markers tested for DNA fingerprints between male and female plants.

Numbers of male and female samples used for each marker are indicated in brackets as $\mathrm{M}$ and $F$, respectively. 
1 Table 1. Total markers tested for DNA fingerprints between male and female plants. Numbers of

2 male and female samples used for each marker are indicated in brackets as $\mathrm{M}$ and $\mathrm{F}$,

3 respectively.

\begin{tabular}{|c|c|c|c|c|c|}
\hline \multirow{3}{*}{ Marker } & \multicolumn{2}{|l|}{ Total } & \multicolumn{2}{|c|}{ Polymorphic Sex } & \multirow{2}{*}{$\begin{array}{l}\text { Sex- } \\
\text { linked }\end{array}$} \\
\hline & tested & Amplifiable & marker & polymorphic & \\
\hline & markers & & (loci) & loci & marker \\
\hline RAPD & 1 & $1(\mathrm{~F} 23: \mathrm{M} 20)$ & 0 & 0 & - \\
\hline AFLP & 36 & 36 (F46:M26) & 13 (141 loci) & 0 & - \\
\hline SCoTs & 36 & 36 (F4:M4) & 3 & 0 & - \\
\hline $\mathrm{SCoTs} / \mathrm{A}$ & 36 & 36 (F4:M4) & 3 & 0 & - \\
\hline SCoTs (36)/EST-SSRs (3) & 108 & 64 (F4:M4) & 7 (7 loci) & 2 (F8:M8) & - \\
\hline SCoTs (36)/TEs (11) & 396 & 163 (F4:M4) & 21 (48 loci) & 48 (F4:M4) & - \\
\hline Oil palm ILPs & 41 & 36 (F3:M3) & 0 & 0 & - \\
\hline Date palm gSSRs & & & & & \\
\hline (high PIC values) & 5 & 2 (F4:M4) & 0 & 0 & - \\
\hline Oil palm EST-SSRs & 289 & 150 (F20:M20) & 11 (17 loci) & 0 & - \\
\hline Oil palm gSSRs & 256 & 168 (F20:M20) & 8 (12 loci) & 0 & - \\
\hline Total & 1,204 & 583 & $66(231)$ & 50 & - \\
\hline
\end{tabular}


Table 2 (on next page)

Clone selection of SSH between male and female. 
1 Table 2. Clone selection of SSH between male and female.

\begin{tabular}{lll}
\hline Library & Female & Male \\
\hline Direct cloning by blue-white colony selection & 9,820 & 2,574 \\
Fragment size $>$ 500 bp by PCR screening & 4,097 & 1,288 \\
Dot blot hybridization I & 498 & 112 \\
Dot blot hybridization II & 63 & 81 \\
BlastX & 29 & 60 \\
\hline
\end{tabular}

2 


\section{Table 3 (on next page)}

The list of enzymes in starch and sucrose metabolism (KEGG map00500) identified in male and female transcripts from inflorescences of Asian Palmyra palm. 
1 Table 3. The list of enzymes in starch and sucrose metabolism (KEGG map00500) identified in 2 male and female transcripts from inflorescences of Asian Palmyra palm.

\begin{tabular}{|c|c|c|}
\hline Enzyme & EC number & $\begin{array}{l}\text { Number of } \\
\text { transcripts }\end{array}$ \\
\hline decarboxylase & $\mathrm{EC}: 4.1 .1 .35$ & 11 \\
\hline phosphodismutase & $\mathrm{EC}: 2.7 .1 .41$ & 1 \\
\hline endo-1,4-beta-D-glucanase & $\mathrm{EC}: 3.2 .1 .4$ & 56 \\
\hline saccharogen amylase & $\mathrm{EC}: 3.2 .1 .2$ & 42 \\
\hline glycogenase & $\mathrm{EC}: 3.2 .1 .1$ & 20 \\
\hline 1,4-alpha-galacturonidase & EC:3.2.1.67 & 5 \\
\hline isomerase & EC:5.3.1.9 & 6 \\
\hline alpha-glucosidase & EC:3.2.1.48 & 42 \\
\hline 1,3-beta-glucosidase & $\mathrm{EC}: 3.2 .1 .58$ & 6 \\
\hline adenylyltransferase & EC:2.7.7.27 & 15 \\
\hline maltase & $\mathrm{EC}: 3.2 .1 .20$ & 2 \\
\hline gentiobiase & EC:3.2.1.21 & 106 \\
\hline synthase & EC:2.4.1.34 & 39 \\
\hline trehalase & $\mathrm{EC}: 3.2 .1 .28$ & 5 \\
\hline invertase & $\mathrm{EC}: 3.2 .1 .26$ & 45 \\
\hline beta-glucuronide glucuronohydrolase glucuronidase & $\mathrm{EC}: 3.2 .1 .31$ & 6 \\
\hline endo-1,3-beta-D-glucosidase & EC:3.2.1.39 & 30 \\
\hline 4-alpha-galacturonosyltransferase & $\mathrm{EC}: 2.4 .1 .43$ & 59 \\
\hline 1,4-beta-xylosidase & $\mathrm{EC}: 3.2 .1 .37$ & 29 \\
\hline
\end{tabular}




\begin{tabular}{|c|c|c|}
\hline phosphorylase & EC:2.4.1.1 & 28 \\
\hline branching enzyme & $\mathrm{EC}: 2.4 .1 .18$ & 7 \\
\hline 1-naphthol glucuronyltransferase & $\mathrm{EC}: 2.4 .1 .17$ & 33 \\
\hline synthase (UDP-forming) & $\mathrm{EC}: 2.4 .1 .15$ & 29 \\
\hline synthase & $\mathrm{EC}: 2.4 .1 .14$ & 18 \\
\hline synthase & $\mathrm{EC}: 2.4 .1 .13$ & 44 \\
\hline synthase (UDP-forming) & $\mathrm{EC}: 2.4 .1 .12$ & 98 \\
\hline synthase & $\mathrm{EC}: 2.4 .1 .11$ & 24 \\
\hline disproportionating enzyme & $\mathrm{EC}: 2.4 .1 .25$ & 8 \\
\hline synthase (glycosyl-transferring) & $\mathrm{EC}: 2.4 .1 .21$ & 13 \\
\hline pectin depolymerase & $\mathrm{EC}: 3.2 .1 .15$ & 75 \\
\hline diphosphatase & EC:3.6.1.9 & 9 \\
\hline glucokinase (phosphorylating) & EC:2.7.1.2 & 14 \\
\hline hexokinase type IV glucokinase & EC:2.7.1.1 & 44 \\
\hline fructokinase (phosphorylating) & EC:2.7.1.4 & 35 \\
\hline trehalose 6-phosphatase & $\mathrm{EC}: 3.1 .3 .12$ & 58 \\
\hline 4-epimerase & EC:5.1.3.6 & 4 \\
\hline diphosphatase & $\mathrm{EC}: 3.6 .1 .21$ & 7 \\
\hline phosphatase & $\mathrm{EC}: 3.1 .3 .24$ & 6 \\
\hline uridylyltransferase & EC:2.7.7.9 & 7 \\
\hline pectin demethoxylase & $\mathrm{EC}: 3.1 .1 .11$ & 69 \\
\hline synthase & $\mathrm{EC}: 2.4 .2 .24$ & 6 \\
\hline (alpha-D-glucose-1,6-bisphosphate-dependent) & EC:5.4.2.2 & 9 \\
\hline
\end{tabular}


beta-pgm (gene name)

6-dehydrogenase
$\mathrm{EC}: 5.4 .2 .6$

EC:1.1.1.22
3

14

3 
Table 4 (on next page)

Enriched GO terms of male- and female-specific transcripts (FDR $<1 \mathrm{E}-02$ ). 
1 Table 4. Enriched GO terms of male- and female-specific transcripts (FDR $<1 \mathrm{E}-02)$.

Enriched female

\begin{tabular}{|c|c|c|c|c|c|}
\hline Go term & Cat & FDR & Go term & Cat & FDR \\
\hline $\begin{array}{l}\text { carbohydrate metabolic } \\
\text { process [GO:0005975] }\end{array}$ & $\mathrm{P}$ & $4.98 \mathrm{E}-05$ & $\begin{array}{l}\text { L-allo-threonine aldolase } \\
\text { activity [GO:0008732] }\end{array}$ & $\mathrm{F}$ & $1.12 \mathrm{E}-09$ \\
\hline $\begin{array}{l}\text { phosphoribulokinase activity } \\
\text { [GO:0008974] }\end{array}$ & $\mathrm{F}$ & $4.98 \mathrm{E}-05$ & $\begin{array}{l}\text { threonine aldolase activity } \\
\text { [GO:0043876] }\end{array}$ & $\mathrm{F}$ & $1.12 \mathrm{E}-09$ \\
\hline $\begin{array}{l}\text { cell wall organization or } \\
\text { biogenesis [GO:0071554] }\end{array}$ & $\mathrm{P}$ & 4.98E-05 & $\begin{array}{l}\text { aspartate family amino acid } \\
\text { catabolic process } \\
\text { [GO:0009068] }\end{array}$ & $\mathrm{P}$ & $1.34 \mathrm{E}-08$ \\
\hline $\begin{array}{l}\text { plant-type cell wall } \\
\text { organization or biogenesis } \\
\text { [GO:0071669] }\end{array}$ & $\mathrm{P}$ & $1.09 \mathrm{E}-03$ & $\begin{array}{l}\text { threonine catabolic process } \\
\text { [GO:0006567] }\end{array}$ & $\mathrm{P}$ & $1.34 \mathrm{E}-08$ \\
\hline $\begin{array}{l}\text { fucose metabolic process } \\
\text { [GO:0006004] }\end{array}$ & $\mathrm{P}$ & $1.09 \mathrm{E}-03$ & $\begin{array}{l}\text { glycine biosynthetic process } \\
\text { [GO:0006545] }\end{array}$ & $\mathrm{P}$ & $3.60 \mathrm{E}-08$ \\
\hline $\begin{array}{l}\text { cell wall biogenesis } \\
\text { [GO:0042546] }\end{array}$ & $\mathrm{P}$ & $1.92 \mathrm{E}-03$ & $\begin{array}{l}\text { isovaleryl-CoA } \\
\text { dehydrogenase activity } \\
\text { [GO:0008470] }\end{array}$ & $\mathrm{F}$ & $9.54 \mathrm{E}-06$ \\
\hline $\begin{array}{l}\text { plant-type secondary cell wall } \\
\text { biogenesis [GO:0009834] }\end{array}$ & $\mathrm{P}$ & $2.50 \mathrm{E}-03$ & $\begin{array}{l}\text { threonine metabolic process } \\
\text { [GO:0018927] }\end{array}$ & $\mathrm{P}$ & $1.20 \mathrm{E}-05$ \\
\hline $\begin{array}{l}\text { plant-type cell wall biogenesis } \\
\text { [GO:0009832] }\end{array}$ & $P$ & $2.50 \mathrm{E}-03$ & $\begin{array}{l}\text { simple leaf morphogenesis } \\
\text { [GO:0060776] }\end{array}$ & $\mathrm{P}$ & $8.86 \mathrm{E}-05$ \\
\hline $\begin{array}{l}\text { cellular carbohydrate } \\
\text { biosynthetic process } \\
\text { [GO:0034637] }\end{array}$ & $\mathrm{P}$ & $2.50 \mathrm{E}-03$ & $\begin{array}{l}\text { branched-chain amino acid } \\
\text { catabolic process } \\
\text { [GO:0009083] }\end{array}$ & $\mathrm{P}$ & $1.65 \mathrm{E}-04$ \\
\hline $\begin{array}{l}\text { carbohydrate biosynthetic } \\
\text { process [GO:0016051] }\end{array}$ & $\mathrm{P}$ & $2.50 \mathrm{E}-03$ & $\begin{array}{l}\text { leucine catabolic process } \\
\text { [GO:0006552] }\end{array}$ & $\mathrm{P}$ & $1.34 \mathrm{E}-03$ \\
\hline $\begin{array}{l}\text { pyrimidine nucleoside salvage } \\
\text { [GO:0043097] }\end{array}$ & $P$ & $3.12 \mathrm{E}-03$ & $\begin{array}{l}\text { AMP biosynthetic process } \\
\text { [GO:0006167] }\end{array}$ & $\mathrm{P}$ & $1.41 \mathrm{E}-03$ \\
\hline $\begin{array}{l}\text { O-acetyltransferase activity } \\
\text { [GO:0004026] }\end{array}$ & $\mathrm{F}$ & $3.43 \mathrm{E}-03$ & $\begin{array}{l}\text { AMP metabolic process } \\
\text { [GO:0046033] }\end{array}$ & $\mathrm{P}$ & $1.41 \mathrm{E}-03$ \\
\hline Membrane [GO:0016020] & $\mathrm{C}$ & 4.19E-03 & $\begin{array}{l}\text { methylated histone binding } \\
\text { [GO:0035064] }\end{array}$ & $\mathrm{F}$ & $1.41 \mathrm{E}-03$ \\
\hline $\begin{array}{l}\text { uridine kinase activity } \\
\text { [GO:0004849] }\end{array}$ & $\mathrm{F}$ & $4.50 \mathrm{E}-03$ & $\begin{array}{l}\text { adenylosuccinate synthase } \\
\text { activity [GO:0004019] }\end{array}$ & $\mathrm{F}$ & $1.41 \mathrm{E}-03$ \\
\hline $\begin{array}{l}\text { nucleoside salvage } \\
\text { [GO:0043174] }\end{array}$ & $\mathrm{P}$ & $4.50 \mathrm{E}-03$ & $\begin{array}{l}\text { PeBoW complex } \\
\text { [GO:0070545] }\end{array}$ & $\mathrm{C}$ & $1.41 \mathrm{E}-03$ \\
\hline $\begin{array}{l}\text { plant-type cell wall } \\
\text { organization [GO:0009664] }\end{array}$ & $\mathrm{P}$ & $5.70 \mathrm{E}-03$ & $\begin{array}{l}\text { cellular amino acid } \\
\text { catabolic process } \\
\text { [GO:0009063] }\end{array}$ & $\mathrm{P}$ & $1.41 \mathrm{E}-03$ \\
\hline $\begin{array}{l}\text { single-organism carbohydrate } \\
\text { metabolic process } \\
\text { [GO:0005975] }\end{array}$ & $\mathrm{P}$ & $5.83 \mathrm{E}-03$ & $\begin{array}{l}\text { phosphoacetylglucosamine } \\
\text { mutase activity } \\
\text { [GO:0004610] }\end{array}$ & $\mathrm{F}$ & $1.74 \mathrm{E}-03$ \\
\hline Endosome [GO:0005768] & $\mathrm{C}$ & $6.68 \mathrm{E}-03$ & de novo' AMP biosynthetic & $P$ & $2.33 \mathrm{E}-03$ \\
\hline
\end{tabular}

Enriched male 
process [GO:0044208]

cell wall organization [GO:0071555]

$\mathrm{P}$

8.97E-03

leucine metabolic process

[GO:006551]

P 3.20E-03

geranylgeranyl-diphosphate

geranylgeranyltransferase $\quad F \quad 3.26 \mathrm{E}-03$

activity [GO:0016767]

ELL-EAF complex

[GO:0032783]

C $\quad 6.81 \mathrm{E}-03$

regulation of rRNA

processing [GO:2000232]

P $\quad 9.23 \mathrm{E}-03$

2 P: Process, F: Function, C: Cellular 


\section{Table 5 (on next page)}

Differential expressed transcripts between sexes with transcript length $>300 \mathrm{bp}$, FPKM $>5$ and $\mathrm{GO}$ terms.

S1 and S2 indicate tested samples. 
1 Table 5. Transcripts differentially expressed between sexes.

\begin{tabular}{|c|c|c|c|c|c|c|c|}
\hline \multirow[t]{2}{*}{ Transcript IDs } & & sted & \multirow{2}{*}{$\begin{array}{l}\text { FPKM } \\
\text { S1 }\end{array}$} & \multirow{2}{*}{$\begin{array}{l}\text { FPKM } \\
\text { S2 }\end{array}$} & \multirow{2}{*}{$\begin{array}{l}\text { Fold } \\
\text { change } \\
(\log 2)\end{array}$} & \multirow[t]{2}{*}{$q$ value } & \multirow[t]{2}{*}{ Blast2GO annotation } \\
\hline & $\mathrm{S} 1$ & $\mathrm{~S} 2$ & & & & & \\
\hline c129593_g1_i1 ${ }^{a}$ & FO & $\mathrm{MO}$ & 7.700 & 63.365 & 3.041 & 0.0241 & auxin-induced 15A-like (Cao et al., 2006) \\
\hline c42126_g1_i1 ${ }^{a}$ & $\mathrm{FO}$ & $\mathrm{MO}$ & 25.601 & 163.217 & 2.673 & 0.0471 & glucan endo-1,3-beta-glucosidase 13 (Nagai et al., 1999) \\
\hline c1819_g1_i1 ${ }^{a, b}$ & FO & MY & 1738.540 & 99.632 & -4.125 & 0.0383 & $\begin{array}{l}\text { ethylene-responsive transcription factor 4-like (Liu et al., 2008; } \\
\text { Tao et al., 2018) }\end{array}$ \\
\hline c142400_g1_i1 ${ }^{a, b}$ & $\mathrm{FO}$ & MY & 949.073 & 68.455 & -3.793 & 0.0087 & $\begin{array}{l}\text { ethylene-responsive transcription factor ERF017-like (Liu et } \\
\text { al., 2008; Tao et al., 2018) }\end{array}$ \\
\hline c128418_g1_i1 ${ }^{a}$ & FY & $\mathrm{MO}$ & 6.541 & 146.348 & 4.484 & 0.0151 & floricaula leafy homolog (Blázquez et al., 1997) \\
\hline c119992_g1_i1 ${ }^{a}$ & $\mathrm{FO}$ & $\mathrm{MO}$ & 4.834 & 59.838 & 3.630 & 0.0383 & galactinol synthase 1-like (Fan et al., 2017) \\
\hline c138805_g1_i2 ${ }^{a}$ & FO & MY & 4.267 & 34.496 & 3.015 & 0.0491 & argonaute 10 (Nonomura et al., 2007) \\
\hline c211381_g1_i1 & FY & MO & 69.478 & 575.104 & 3.049 & 0.0241 & anti-muellerian hormone type- 2 receptor [Arabidopsis thaliana] \\
\hline c140985_g1_i1 & FY & MY & 130.511 & 20.195 & -2.692 & 0.0409 & ASPARTIC PROTEASE IN GUARD CELL 2-like \\
\hline c195337_g1_i1 & FY & MO & 44.752 & 547.920 & 3.614 & 0.0151 & CASP 2C1 \\
\hline
\end{tabular}




\begin{tabular}{|c|c|c|c|c|c|c|c|}
\hline c127228_g1_i1 & FY & $\mathrm{MO}$ & 71.119 & 6.415 & -3.471 & 0.0328 & cellulose synthase A catalytic subunit 4 [UDP-forming] \\
\hline c131838_g1_i1 & FY & MY & 20.253 & 2.104 & -3.267 & 0.0289 & cellulose synthase A catalytic subunit 9 [UDP-forming]-like \\
\hline c145948_g1_i1 & FY & $\mathrm{MO}$ & 26.670 & 177.451 & 2.734 & 0.0448 & F-box GID2-like \\
\hline c124632_g1_i2 & FY & MO & 3.413 & 43.070 & 3.658 & 0.0383 & high mobility group B 7 [Nelumbo nucifera] \\
\hline c125833_g1_i2 & $\mathrm{FO}$ & MY & 181.228 & 30.473 & -2.572 & 0.0460 & ingression fic1-like \\
\hline c104934_g1_i1 & FY & MY & 5.703 & 70.065 & 3.619 & 0.0442 & long-chain-alcohol oxidase FAO4A \\
\hline c138788_g1_i1 & FY & MY & 483.513 & 19.217 & -4.653 & 0.0133 & NDR1 HIN1-Like 3-like \\
\hline c106063_g1_i1 & FO & MY & 458.018 & 47.014 & -3.284 & 0.0198 & nuclease HARBI1 \\
\hline c181538_g1_i1 & FO & MY & 431.202 & 34.566 & -3.641 & 0.0087 & nuclease HARBI1 \\
\hline c134717_g2_i1 & FO & MY & 580.064 & 54.540 & -3.411 & 0.0210 & nuclease HARBI1 \\
\hline c126031_g2_i3 & FO & MY & 142.996 & 13.803 & -3.373 & 0.0210 & nuclease HARBI1 \\
\hline c126031_g2_i2 & $\mathrm{FO}$ & MY & 233.676 & 27.069 & -3.110 & 0.0380 & nuclease HARBI1 \\
\hline c116702_g1_i1 & FO & MY & 116.085 & 6.274 & -4.210 & 0.0133 & peroxidase 3 -like \\
\hline c129100_g1_i2 & FO & $\mathrm{MO}$ & 2.660 & 33.248 & 3.644 & 0.0375 & probable 2-aminoethanethiol dioxygenase \\
\hline c98445_g1_i1 ${ }^{b}$ & FY & MY & 172.349 & 8.685 & -4.311 & 0.0380 & probable WRKY transcription factor 25 \\
\hline c129627_g1_i4 ${ }^{b}$ & FY & MO & 3.978 & 64.185 & 4.012 & 0.0292 & probable WRKY transcription factor 65 \\
\hline
\end{tabular}




\begin{tabular}{|c|c|c|c|c|c|c|c|}
\hline c141291_g1_i12 & FO & MY & 309.255 & 51.579 & -2.584 & 0.0409 & probable xyloglucan endotransglucosylase hydrolase 23 \\
\hline c141291_g1_i9 & $\mathrm{FO}$ & MY & 141.769 & 24.912 & -2.509 & 0.0500 & probable xyloglucan endotransglucosylase hydrolase 23 \\
\hline c128725_g1_i1 & $\mathrm{FO}$ & MY & 149.511 & 9.942 & -3.911 & 0.0472 & probable xyloglucan endotransglucosylase hydrolase 23 \\
\hline c105494_g1_i1 & $\mathrm{FO}$ & MY & 102.967 & 14.931 & -2.786 & 0.0409 & probable xyloglucan endotransglucosylase hydrolase 23 \\
\hline c118421_g1_i2 & FY & MY & 54.923 & 2.674 & -4.361 & 0.0241 & remorin [Eucalyptus grandis] \\
\hline c138049_g1_i1 & FY & $\mathrm{MO}$ & 56.348 & 336.410 & 2.578 & 0.0472 & signal $[$ Medicago truncatula $]$ \\
\hline c108722_g1_i1 & FY & MO & 37.435 & 654.878 & 4.129 & 0.0472 & signal [Medicago truncatula] \\
\hline c135861_g1_i2 & FY & $\mathrm{MO}$ & 38.893 & 3.975 & -3.290 & 0.0383 & trans-resveratrol di-O-methyltransferase-like \\
\hline c126812_g1_i2 ${ }^{b}$ & $\mathrm{FO}$ & MY & 117.456 & 12.564 & -3.225 & 0.0133 & transcription factor bHLH94-like \\
\hline c126812_g1_i1 ${ }^{b}$ & $\mathrm{FO}$ & MY & 71.762 & 5.114 & -3.811 & 0.0241 & transcription factor bHLH94-like \\
\hline c136093_g2_i1 ${ }^{b}$ & $\mathrm{FO}$ & MY & 91.163 & 8.193 & -3.476 & 0.0133 & transcription factor bHLH94-like \\
\hline c155603_g1_i1 & FY & MY & 155.137 & 17.684 & -3.133 & 0.0380 & U-box domain-containing 25-like \\
\hline c82639_g1_i1 & FY & $\mathrm{MO}$ & 87.025 & 10.838 & -3.005 & 0.0292 & U-box domain-containing 26-like \\
\hline c139774_g4_i1 & FY & MY & 192.281 & 28.590 & -2.750 & 0.0472 & UPF04964 \\
\hline c135252_g1_i1 & $\mathrm{FO}$ & MY & 40.178 & 2.638 & -3.929 & 0.0198 & VQ motif-containing 4-like \\
\hline c137964_g3_i1 & FY & MO & 30.285 & 441.859 & 3.867 & 0.0380 & Ycf68 (chloroplast) [Carnegiea gigantea] \\
\hline
\end{tabular}


c137478_g2_i2 FY MO $50.030 \quad 369.658 \quad 2.885 \quad 0.0241$ ycf68 [Medicago truncatula $]$

2 Transcript length $>300 \mathrm{bp}$, FPKM $>5$

$3 a$ involved in sex determination and flower development.

$4{ }^{b}$ with high FMKM values. 


\section{Figure 1}

Asian Palmyra palm samples from male and female plants.

Asian Palmyra palm samples from male and female plants. (A) A mature male plant with a fully developed male inflorescence and (B) a mature female plant with a female inflorescence bearing fruits. (C) and (D) Representatives of developing male inflorescences from young to mature stages. (E) Representatives of developing female inflorescences, and (F) buds extracted from female inflorescences. (G-J) Representative female and male inflorescence samples used for the SSH experiment ( $\mathrm{G}$ and $\mathrm{H}$, respectively) and de novo transcriptome sequencing analysis (I and J, respectively). Scale bars are indicated within. 


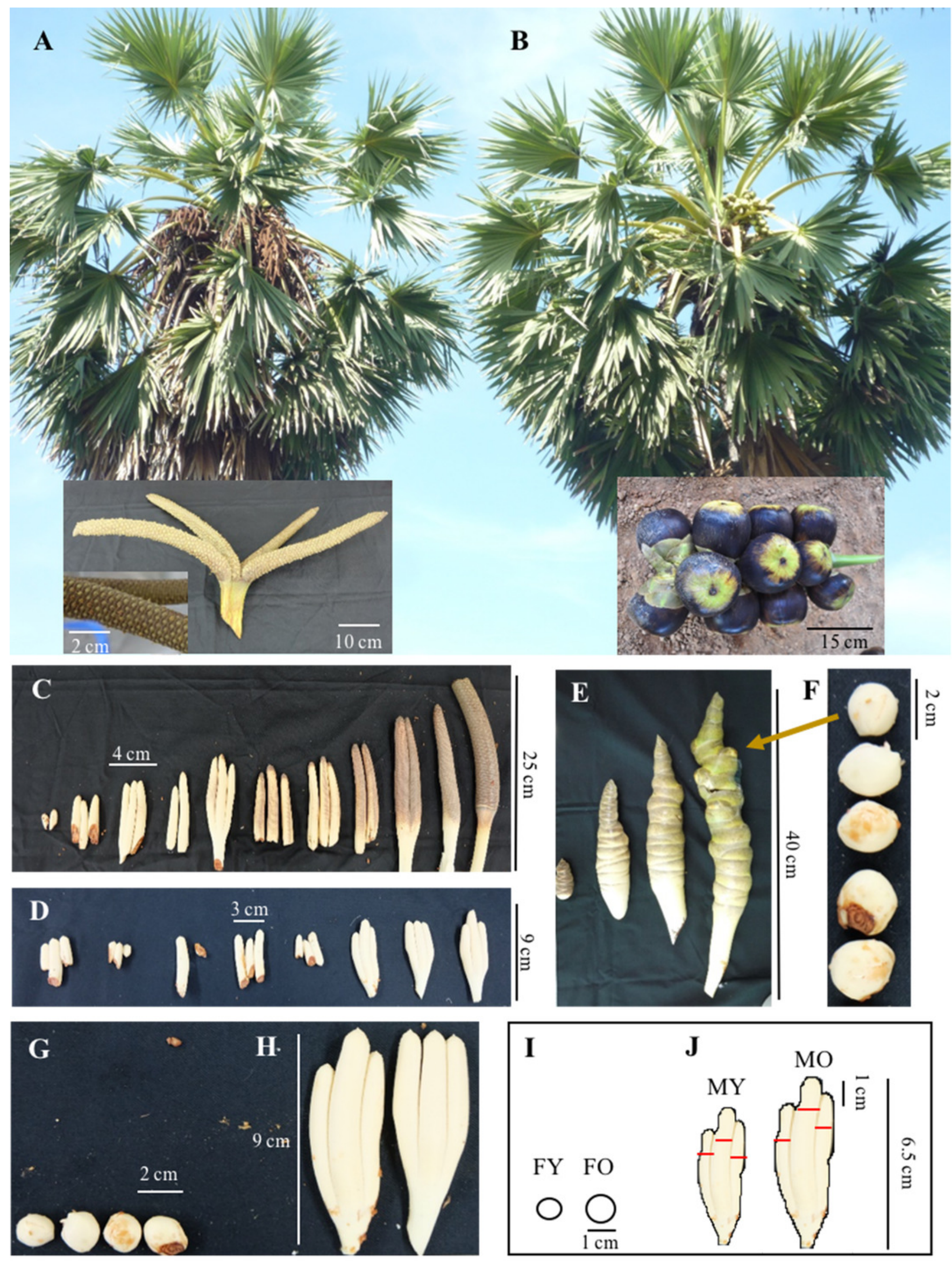


Figure 2

De novo transcriptome sequencing overview.

(A) total sequence reads (bp) after trimming and removing low quality read ( $<$ Q20) of four samples. (B) Distribution of number and length of assembled transcripts, and (C) sequence similarity of assembled transcripts to other plant species. 
A

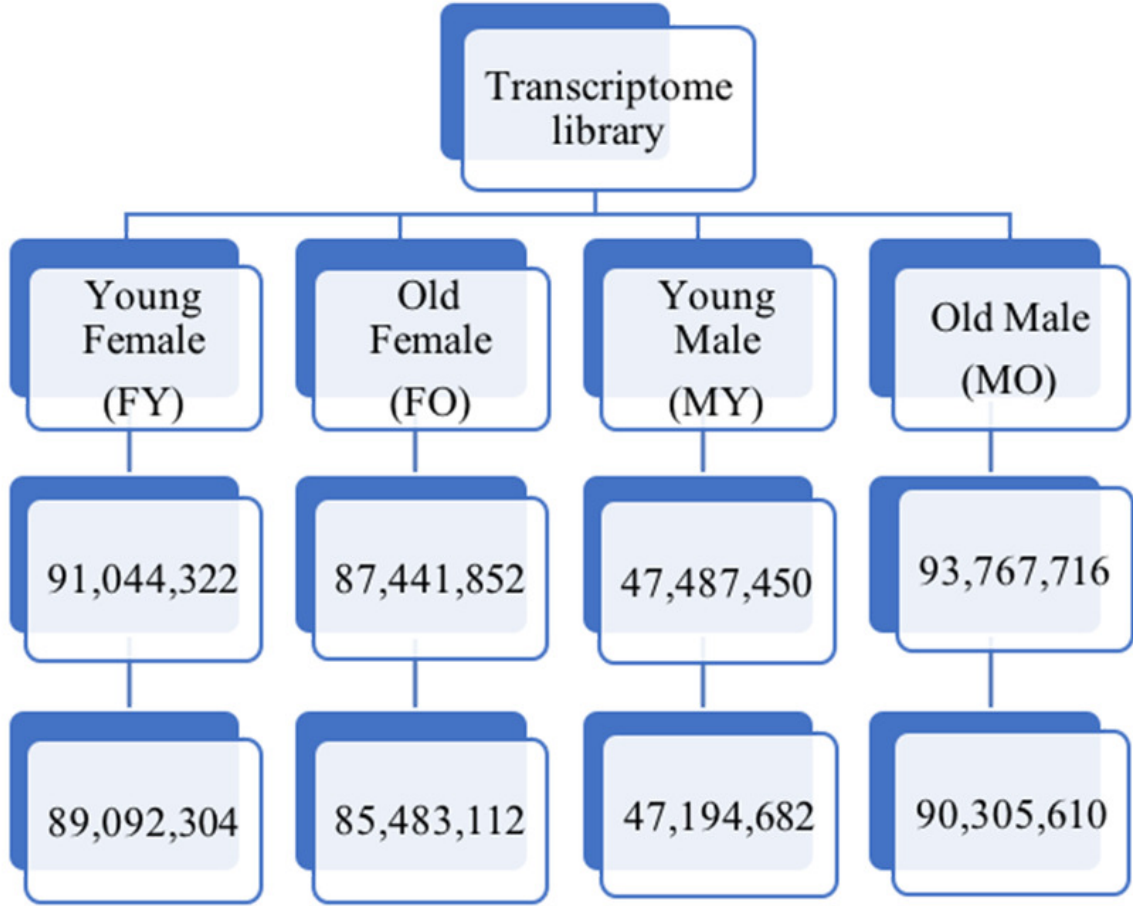

B

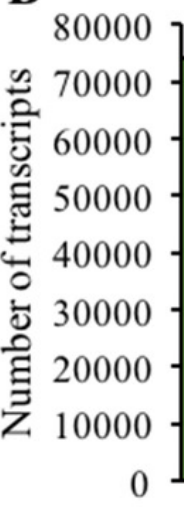

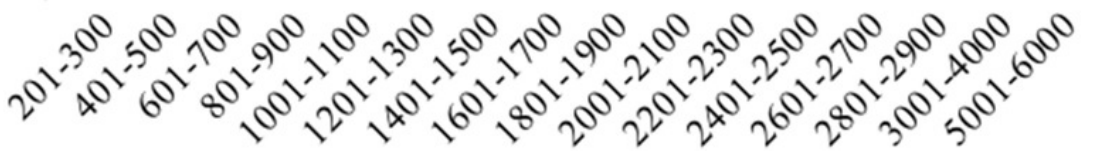

Length (bp)

C

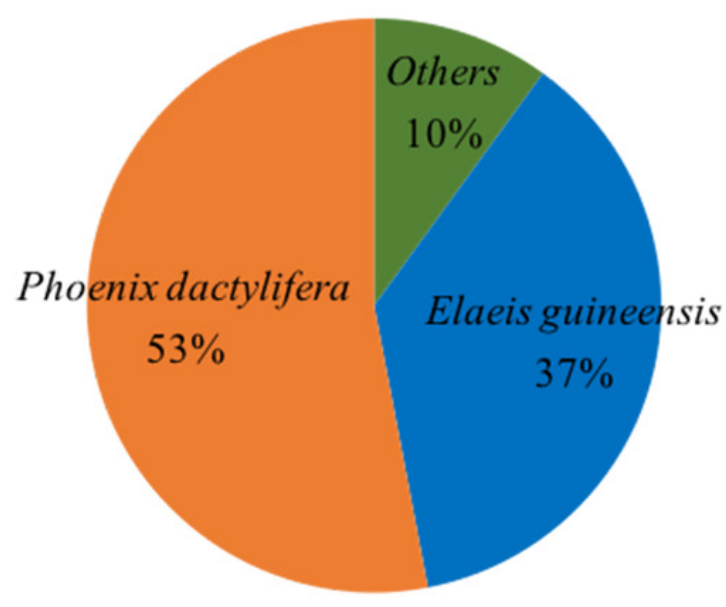


Figure 3

Mapping of assembled transcripts onto the starch and sucrose metabolism (map00500) taken from KEGG.

Mapped enzymes are indicated by colors (see Table S10 for details). Kanehisa Laboratories $005005 / 9 / 16$.

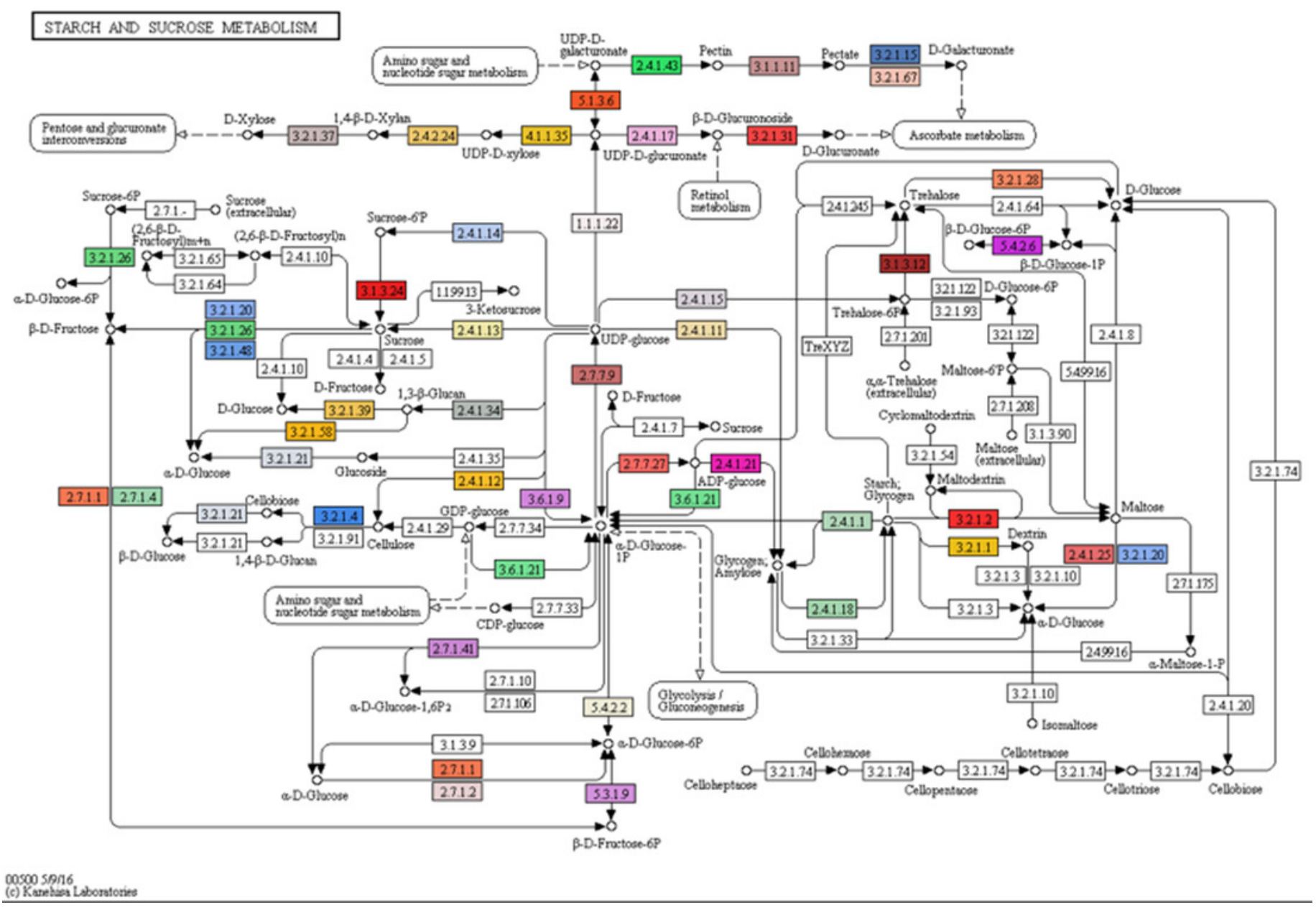


Figure 4

Fig. 4. A Venn diagram of four transcript datasets.

Numbers and percentages of transcripts are indicated.

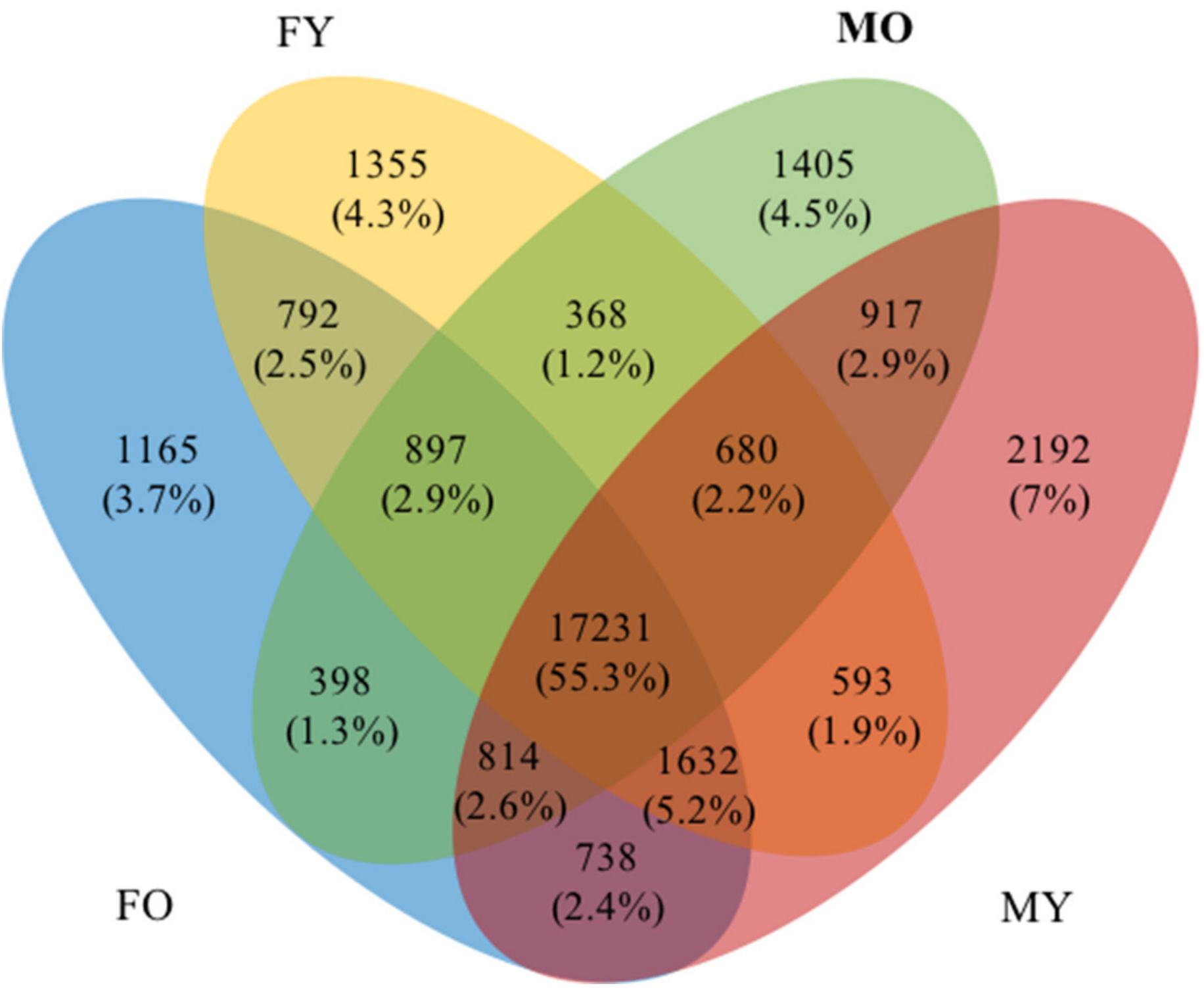

